\title{
Main problems of the development of fruit and berry raw materials processing industry in the Russian Federation
}

\author{
Natalya Gribova ${ }^{1, *}$, Lydia Berketova ${ }^{1}$, Vitaly Perov ${ }^{1}$, Lyudmila Lipatova, and Natalya \\ Soltaeva ${ }^{2}$ \\ ${ }^{1}$ Plekhanov Russian University of Economic, Stremyanny pereulok, 36, Moscow, 117997, Russia \\ ${ }^{2}$ Russian State University of Tourism and Services Studies, 99, street Glavnaya, p. Cherkizovo, \\ Pushkinsky District, Province of Moscow, Pushkino, Moscow Oblast, 141221, Russia
}

\begin{abstract}
Food safety is one of the most important and actual problems of the humanity. It is well-known and approved that a country is in safe food situation only in case when it independently produces essential foodstuffs at least $80 \%$ of its self-sufficiency level. The current situation is forcing us to achieve the independence from imports. In our research, we make an accent to farther development in the domestic fruit and berry manufacturing processes, which implies general enlarging the product assortment and making it available for customers countrywide. To re-tool the industry with hi-end equipment; to improve raw material storage bases, located in the regions of most intensive consumption; to develop and introduce some innovative and ecologically safe fruit and berry raw materials processing technologies. To pay an extra attention to quality and safety of fruit and berry raw material and ready product. To expand production of canned, frozen, dried products assortment and make it ecologically clean and highly competitive compared to the imported ones. In addition, to make marketing analysis on the attractiveness of a product package for customers and dispose of dependence between processing enterprises and raw material bases.
\end{abstract}

\section{Introduction}

Since the Russian Federation joined the World Trade Organization, the need to develop and raise its own food industry has become more evident than ever. To the present day, in the conditions of the modern stage in market relations, this problem still remains relevant. It is an obvious influence result of multiple various barriers and negative factors: they all create serious limits for the industrial and economic potential of national processing enterprises.

Competition with manufacturers of the imported products and foreign goods remains intense; therefore, the actual conditions for fruit and berry raw material processing industry are remaining difficult. At the same time, this industry provides food safety of both each

*Corresponding author: natali-g@bk.ru 
individual region and the country as a whole. In other words, it is involved in making the existence of a society comfortable in the economic and social aspect [1-3]. The Russian national market of fruit and berry products still exists in the development regime. It's obvious that national funding can play a great role for increasing its efficiency.

Food safety still remains an important problem for all the society. Supplying people with food, especially safe products, is an important stage to provide stability in the country, and, moreover, in the whole world. It is stated in the international rules that achieving a safe food situation in the country demands to produce at least $80 \%$ of the consumed foodstuffs inside its borders by native manufacturers [2-4].

The conception of «Food safety» was ratified in 1974, at the World Food Conference. It considers such circumstances, when every person in population of the country has physical and economic permanent opportunities for getting safe and nutritional provision in such an amount, which is able to satisfy their needs and preferences in food, and able to provide active and healthy life of people [5].

In Russian laws, such a concept appears in the first time in the Federal target program for 1996-2000 years, intended to stabilize and develop the sector of an agro-industrial production. "Achieving food safety» was introduced and pointed in the field of food production and consumption as a primary task of new national policy $[5,6]$.

For the national economy, as well as for its agro-cultural complex, providing the food safety means that all the needs of citizens for food, in accordance with normatives of rational and healthy nutrition would be satisfied without using the state food reserve [7].

In the 21 January of 2020 the «Russian Federation food safety doctrine» was accepted, according to this conception. It represents official views for the targets and tasks and main directions of the state social and economic policy to provide food safety in the country [2, $5,7]$.

The agro-industrial complex of the country needs to cope with a global and priority task - to provide food safety in each region. Finding the decision should help to improve the life quality level of all the country population, and provide high living standards for them. Achieving it is possible through stabilizing domestic manufacturing, having all the necessary resources in-stock $[1,6]$. However, the current situation is favorable not in all segments of the food market. In 2014, due to the prohibition of importing raw materials and products from countries of the European Union, the USA, Canada Australia and Norway, a serious lack of fruits and berries has occurred. Then Russian Agriculture Ministry revealed, that self-sufficiency in this products amounts only a third part of planned indicators. In the country has severely escalated the situation, related with food safety of production supplied by west countries for Russian consumers. An academician E.N. Krylatykh noted this problem; she admitted that in recent years, the treat of a global food crisis has increased due to large-scale growth of hunger in - for example - African countries [8]. Therefore, the study of the potential for formation and development of fruits and berries market in Russia is an urgent scientific task.

\section{Develop national horticultural enterprises in Russia}

This research was done to study the main problems and ways to develop national horticultural enterprises, as well as processing enterprises, producing of fruit and berry raw materials in Russia.

In the specific of market relations, domestic agro-cultural enterprises are not interested in investing their own funds in development of horticultural business. The reason is a long durability of the payback period. It is obvious, that without budget funding, any effective development of the Russian horticulture would be impossible. In the negative script, in the future, it can lead to a raw material shortage in all domestic fruit and berry industry. 
Therefore, even less raw material would be available for processing. That is why domestic products are overpriced and presented in limited amounts on the market, and products imported to Russia from foreign countries still prevail $[9,10]$.

Such a high-scale decline in the national horticulture led to serious deficit of raw materials and, consequently, to a recession in all the processing industry. Because of high taxes and without of government support, private horticultural enterprises simply could not stay on the domestic market in such conditions. That's why our customers are offered very expensive fruit and berry production. At the same time, private farms have high-quality raw material resources and final products matching all customer's criteria.

An academician E.N. Krylatykh has suggested to accelerate the development of agroindustrial complex, especially its highly profitable sectors to solve the food safety problem. She believes that this will allow the manufacturers to get more profit (as well as the country population as a whole). Simultaneously, the growing income also will provoke a growth in the scale of production and, subsequently, will lead to general stabilization and price stability on the national market [8].

This strategy already has been researched in the Siberian Federal District by Borisova O.V. and Khropataya I.Yu. A long time ago, such a decision was revealed and the results of the recent fifteen years, and described in GNU SibNIIESH scientific works confirming it [11].

Glotko A.V. in his research drew an attention to the prospects of the Altai region. This region itself is an industrial-agrarian region, and opportunities for industrial and agricultural production, are comparatively equal in this area. It would be wise to use its existing potential to develop the local horticulture [12].

Uskov V.S. offers the conception of development of personal subsidiary farms of fruit and berry products in the European North of Russia. He has analyzed the current situation of this territory; its local resources of fruit and berry products are diversified and presented both in cultivated and wild specimens. It was mentioned, that in the European North of Russia, Agricultural organizations are producing only $0.2 \%$ of all fruit and berry products amount. Literally, in the northern regions of the country, production of fruits and berries in is presented only in the local country yards and household plots. It is known, that market conditions in a farm management are characterized by high costs of fruit and berry cultivation. At the same time, low fertility of the land leads to its low prolificness. Do not forget about short northern summer, therefore growth season is so short. All these factors are obstructing to perform wide development of horticultural farms in the such regions [13].

As a management mechanism for the processes of regional market of fruit and berry products, the author proposes to focus efforts on expanding the use of local industrial complexes for the processing of local resources. He also notes the importance of developing a system of state incentives for small businesses in this industry, up to small private farms.

A conception for the development of fruit and berry products in the region of Krasnodar region was offered by A.A. Kalashnikov. Krasnodar region is known as one of the largest Russian source of fruit and berry products. According to the author's research, main trends in the development of raw material base for fruit and berry products market in Krasnodar region are the following: the total and fruitful areas of perennial plantations in public farms are reducing, meanwhile private household farms are expanding. It leads to a growth in a production of fruits, but intensity of gardening is reducing [14].

Mikhasev R.V. in his scientific papers studies the development of fruit and berry products in Tambov region. First of all, he suggests government regulation as a primary phase, which includes the need for following steps. Making an analysis of market conditions, conducting innovative scientific research for finding the most profitable types and specimens, counting the cost of liquidation old gardens and laying the new ones, 
achieving reduction of tax and providing the national foundation to develop this industry. Also he admits the necessity of decreasing the share of imports and strengthening of the partnership for co-operation between private business and huge distributors [15].

The authors, who studied the problem in the country even earlier, in their research, recommend to increase the scale of berries production in a place such as Altai territory, due to the favorable climatic conditions. Statistic says about an average production of fruits and berries is about 18,2 thousand tons, what means only $7,0 \mathrm{~kg}$ per person per year for this region $[13,15]$. This amount is significantly less than indicated in medical standards, which indicate at least 71 kilograms per person per year.

At the same time, this parameter amounts about 100 to $120 \mathrm{~kg}$ per person in North America and Western Europe. It is curious, that even in the face of such dissatisfaction with consumer demand, producers systematically encounter difficulties in selling fresh fruit and berry products, while usually about $60 \%$ of the total harvest is sold fresh.

To alleviate the difficult situation, Russian government proposed a set of measures for financial support of manufacturers operating in the field of industrial horticulture, aimed at compensating a part of the costs for planting and care. At the same time Russian customers are still suggested mainly import fresh fruit and berry products, which, moreover, are not safe enough.

Since 2015, obligatory terms for entrepreneurs getting the subsidy changes: only 1 hectare (instead of 3 as previously) was enough to receive it. In comparison to previous years, subsidy rates for the traditional orchards was almost 2.3 times, fruit farms about 6.2 times, and about 3.1 times for an intensive orchards. Since 2015, has been introduced an additional form of state support - a payback up to $20 \%$ of direct costs for the construction of fruit storage facilities [13].

Berry growing - is one of the main agricultural branches. There are up to 25 fruits and berries are cultivated in Russia, all of them, represent an importance for economy of the country $[13,15,16]$. Fruits, berries and grapes are widely used fresh, canned, frozen and dried to produce compotes, preserves, jams, marmalades, juices, nectars, etc. In compare with previous years, production of fruits and berries has gradually increased in Russian Federation. That indicates a positive result of the cultivation of gardens in various regions of our country.

Marketing research has shown that the fall of domestic processing industry in the field of various processed (canned, frozen, dried etc.) fruit and berry products in the early $2000 \mathrm{~s}$ is caused by the lack of new technologies and equipment, as well as the inability to restructure its marketing policy in the conditions of modern market economy.

In our opinion, the most actual and global problem in processing raw material of fruits and berries is technological processing. Compared to fruits and vegetables, they have serious disadvantage in durability of their storage period: one to two days only. Therefore, not only the quality of fresh raw materials is important, it is necessary to evaluate all the weaknesses on all the stages: how they are stored, processed, and packaged before selling them.

\section{Problem in processing raw material of fruits}

Currently, about 60 canning and 20 fruit canning enterprises and 35 wine factories are engaged in the fruits and berries processing. The annual demand for fruit and berry raw materials is up to 230 thousand tons. Every year, when total amount of harvested fruits and berries is constantly less than the required one, it leads to inactivity of about $50-60 \%$ of the processing enterprises, which certainly is irrational use of industrial capacities. Involving private amateur and consumer gardens of the republic population, we can compensate this raw materials shortage, and guarantee an increase in the development of fruits and berries 
processing industry directly in the region they are cultivated. At the same time, this will provide favorable conditions for expanding an assortment of processed fruit and berry products of various types $[17,18]$.

The authors performed a comprehensive analysis of the Russian horticulture. There was considered activity of farms, producing fruits and berries, as well as various aspects of processing industry in detail. Such an analysis allowed to reveal the weak and strong points, and as a result, has predetermined the main purpose of the whole research: to create, a strategy, aimed to avoid the food crisis in the country through establishment of new horticultural farms in various regions and republics in the one hand, and to expand fruits and berries production range in the other hand. This strategy requires fulfilling the following stages, as shown in table 1 .

Table 1. Aspects of the strategies of the processing industry

\begin{tabular}{|l|l|}
\hline \multicolumn{1}{|c|}{ Stages } & \multicolumn{1}{|c|}{ Strategy } \\
\hline 1 stage & getting financial support from the government \\
\hline 2 stage & $\begin{array}{l}\text { taking into account the marketing approach in the development of fruits } \\
\text { and berries production }\end{array}$ \\
\hline 3 stage & creating a growing planting material strategy \\
\hline 4 stage & $\begin{array}{l}\text { removing the outdated equipment in the storages for fruit and berry raw } \\
\text { materials with modern one }\end{array}$ \\
\hline 5 stage & $\begin{array}{l}\text { improving the material and technical base used for fruit and berry } \\
\text { processing }\end{array}$ \\
\hline 6 stage & enlarging the assortment of products in the country \\
\hline 7 stage & $\begin{array}{l}\text { using innovative and effective, ecologically safe technologies for } \\
\text { canning, freezing, and drying of fruit and berry products }\end{array}$ \\
\hline
\end{tabular}

It is obvious, that after a stage, when qualitative raw material was harvested, it is important to store it in a proper condition, to ensure its matching all the organoleptic quality criteria. Henceforward, these raw materials are supposed to be processed and sold as a competitive and demanded product for customers.

We recommend to pay an extra attention to expanding an assortment of domestic products, made of fruit and berry raw materials. To solve this complex problem, we offer multiple options. First of all - to grow ecologically clean natural raw materials for the subsequent processing. The authors have a set of patented innovative and competitive methods for different procedures of processing; for example - fruits and berries dehydration by osmotic agents before freezing or drying. There are developed various options for the technological processes, to keep the product quality corresponding all organoleptic criteria and properties, as well as to prevent the presence of harmful substances in their composition. That all is extremely important today.

It is necessary to envisage and apply the waste-free technology for production of fruit and berry products, when various categories of them are produced at one processing enterprise.

When applying these recommendations in practice, there could be a situation, when one of the used methods does not provide economically approved competitive advantages. One of the known ways of regulation is the product final price: in such a script, companies needs finding external sources of funding, and permanently execute a strict control over expenses. It will be useful to adopt some experience of the successfully performing and developing West companies, which confirms, that in the modern market conditions, planning has become a primary function to avoid gaps in process of production management.

An increasing influence of market methods of management, leads the processing enterprises to re-define their subsequent activities according to the role of planning in 
national economy. The sense in the use of planning as a form of government regulation in economy is undoubtedly confirmed by experience of the West countries $[7,19,20]$. In the nearest future, taking to account modern market relation, success in the activity of processing enterprises in Russia requires of a wise commodity strategy. Such a strategy should be integrated to a global development strategy of an enterprise. To develop it, all the factors need a detailed and close attention. It is extremely important to identify the strengths and weaknesses of the company, to assess its level of competitiveness, to perform a detailed analysis of the market.

It is obvious that all this can be done only by resorting to state financial support as well as using evidence-based recommendations, formulated after a comprehensive research, which offer multiple options for development in processing industry of fruit and berry raw materials and products to bring stability in Russian national economy.

At the first stage, the simplest task for solving domestic food problem is a necessity to radically change the equipment in processing enterprises to the modern one, to apply new ecologically clean technologies for processing fruit and berry raw materials. To expand the production of a product range in the field of canning, freezing and drying and to make new high-quality products competitive compared to imported ones.

This scientific article presents only a small part of the comprehensive research carried out by the authors in the field of the development of fruit and berry products and the national market for its implementation. For the development and expansion of the branch for growing berries and fruits in our country, the relevant enterprises need to develop their capacities and increase their competitiveness, as well as take into account all of the above factors that affect these processes. All of these aspects require a detailed scientific approach.

There is no doubt, that all of these stages and changes stated above, will take some time, and only in the future we will find on the market safe and high-quality domestic fruit and berry products, both fresh and processed.

\section{Conclusion}

Everything shows that the Russian Federation has all the necessary circumstances and resources for the successful cultivation of fruits and berries, as well as increasing the scale of their production to ensure their sufficient quantity for the population of the country. But this sector of the market and production is in dire need of global government support. Only with the help of such effective measures, processing enterprises in this industry will help Russia achieve the required level of food safety, and in the end, domestic products will appear on the market in sufficient volumes. Moreover, these products will have higher consumer properties, which mean that buyers will give preference to them. This will put an end to dependence on imported products.

\section{References}

1. I. Minakov, Journal Bulletin of the kursk state agricultural academy, 1, 11-16 (2016)

2. Y. Petrachkova, M. Shatokhin, Journal Bulletin of the kursk state agricultural academy, 1, 3-5 (2015)

3. A. Savelyeva, HSE Economic Journal, 3, 524-538 (2013)

4. P. Mikhaylushkin, Scientific journal of KubSAU, 92, 967-977 (2013)

5. R. Belkin, Journal Bulletin of the kursk state agricultural academy, 3, 31-34 (2012) 
6. I. Pitsyk, Management of economic systems scientific electronic journal, 2(96), 1-15 (2017)

7. A. Kurdiumov, Journal of new economy, 4(42), 103-117 (2012)

8. E. Krylatikh, Russian peasant studies, 2(3), 44-56 (2017)

9. N. Gribova, Science review, 23, 204-207 (2015)

10. L. Eliseeva, Economics: yesterday, today and tomorrow, 9, 92-101 (2016)

11. O. Borisova, Fundamental research, 2(19), 4239-4243 (2015)

12. A. Glotko, Altai state agrarian university bulletin, 68(6), 106-110 (2010)

13. V. Uskov, Economic and social changes: facts, trends, forecast, 4(28), 166-176 (2013)

14. A. Kalashnikov, APK: economics, management, 7, 48-50 (2010)

15. R. Mikhasev, Problems of contemporary science and practice. Vernadsky University, 8(22), (2010)

16. I. Minakov, Journal Bulletin of the kursk state agricultural academy, 9, 3-8 (2016)

17. V. Rokhchin, Economic and social changes: facts, trends, forecast, 4(34), 198-211 (2014)

18. A. Kuzmin, Agro production and econimics, 3, 14-21 (2018)

19. M. Segovia-Villarreal, Raquel Florez-Lopez, Juan Manuel Ramon-Jeronimo, Sustainability, 11, 1-36 (2019) doi: 10.3390/su11102862

20. J. M. Ramon-Jeronimo, R. Florez-Lopez, J. Risk Financial Manag, 11(31), 1-16 (2018) doi: $10.3390 / \mathrm{jrfm} 11030031$ 